\title{
ANMELDELSER
}

\section{SATURINO M. BORRAS JR., MARC EDELMAN \& CRISTOBAL KAY (eds.): Transnational Agrarian Movements Confronting Globalization. Chichester, West Sussex: Wiley-Blackwell 2008. 362 sider. (Oprindeligt udgivet som Vol. 8, Issue 2/3 af Journal of Agrarian Change). ISBN 978-1- 405-19041-1. Pris: \$ 35,72.}

Antropologer interesserer sig ikke udpræget for sociale bevægelser, og at det virkelig er en skam, bliver man hurtigt klar over, efterhånden som man arbejder sig igennem Transnational Agrarian Movements Confronting Globalisation. For dens artikler ville blive en hel del bedre, hvis de var forankret i god og solid etnografisk produceret empiri. Bogens eneste bona fide antropologiske bidragsyder er Marc Edelman - forfatter til den strålende monografi Peasants against Globalization (1999) samt en række artikler om beslægtede temaer - mens de andre forfattere befinder sig inden for geografien, statskundskaben, sociologien eller udviklingsstudier. Og det bærer bogens tilgang til fænomenet transnationale agrare bevægelser præg af. Redaktørerne har valgt at forkorte transnational agrarian movements til "TAM" - samme ord kunne man bruge til at beskrive store dele af bogens indhold, i alt fald som antropolog. Men inden jeg fordyber mig i min antropologiske anke mod nogle af bidragene, skal antologien have den ros, den også fortjener. For bogen er informativ, og man er empirisk en hel del klogere på nogle af verdens transnationale agrare bevægelser og da særligt de mest kendte af dem, for eksempel Via Campesina og den brasilianske Movimento dos Trabalhadores Rurais Sem Terra (MST), når man er vel igennem bogens knap 400 sider.

Bogens redaktører identificerer i deres introduktion tre "tavsheder" i den eksisterende litteratur om sociale bevægelser: 1) Der er meget få studier af agrare bevægelsers interne dynamik og af agrare bevægelser på den transnationale scene, 
2) der er for få studier af dynamikken i de lokale - nationale - globale forbindelser, og 3) der mangler studier, som integrerer analysen af sociale bevægelser med en analyse af forandringerne i agrare relationer og produktionsforhold. Efter min bedste vurdering er tavsheden på disse felter nu ikke total. Indiske rurale og agrare bevægelser har for eksempel løbende været genstand for grundige antropologiske og sociologiske studier, der har gjort brug af de nyeste teorier om sociale bevægelser. Det gælder eksempelvis bidragene i New Farmers 'Movements in India fra 1995 (redigeret af Tom Brass) samt flere nyere artikler af Ron Herring og af enkelte nordiske forskere som Stig Toft Madsen og Staffan Lindberg. Men nuvel: I det store hele rammer redaktørerne formentlig plet med deres tre "tavsheder". Problemet er blot, at det langtfra er alle artiklerne, der formår at bryde tavsheden.

Alle bidragsydere kan deres marxisme og er ikke længe om at identificere globaliseringen og neoliberalismen - som nogle af dem dog meget sigende vælger at skrive i anførselstegn - og den uhellige treenighed WTO, Verdensbanken og IMF som hovedårsagerne til dagens agrare kriser. Gennem tvungne strukturtilpasningsprogrammer, dumping af subsidierede landbrugsvarer fra den store Satan USA og den mindre Satan Europa i udviklingslandene og store multinationale selskaber som Monsanto og deres comprador-kapitalister i den tredje verden bliver landbruget i verdens fattigste lande undermineret, og småbønder kastes ud i fattigdom, forgældelse og nød. Derfor ser man nu en bølge af agrare bevægelser - særligt i Latinamerika og Asien - som formulerer både en kritik af og en række alternativer til den neoliberale globale kapitalisme. Denne analyse er formentlig i det store hele korrekt, selv om vi her bevæger os på et abstraktionsog generaliseringsniveau, hvor mangen en antropolog begynder at få koldsved. Men det er sandelig også en analyse, man har hørt mange gange før, og er det den historie, man vil have serveret, så er det vel bare at spørge de forskellige store agrare bevægelsers ledere og talsmænd eller at læse deres rapporter. For det er jo præcis dette narrativ, som de agrare bevægelser selv søger at fremme gennem al deres transnationale gøren og laden. Og her er vi fremme ved et af bogens metodiske problemer: Forfatterne er generelt sympatisk indstillede over for de bevægelser, de studerer, og mange af deres data er hentet fra de store bevægelsers skriftlige materiale og selvbiografier eller fra interviews med diverse ledere. Og de kan også deres marxisme - og i Latinamerika sikkert også deres afhængighedsteori og deres "NGO speak" - så her indgår forsker og informant i et uheldigt diskursivt fællesskab, hvor de gensidigt kan bekræfte hinandens verdensopfattelser. Det reducerer desværre af og til forskeren til en mikrofonholder for bevægelsernes talsmænd, og det er jo ikke så heldigt. For kan det virkelig passe, at der sådan uden videre foregår en "telefaxinternalisering" - for nu at 
låne en term fra Claudia Strauss - mellem det, lederne siger, er bevægelsens mål, og så det, bevægelsernes mange tilhængere (MST har for eksempel flere millioner) går rundt og drømmer om og kæmper for? Nej, det kan det selvfølgelig ikke. MST er for eksempel imod genmodificerede afgrøder (GM), men mange af MST's tilhængere blandt småbønderne planter GM på livet løs, hvad enten de er Monsanto-producerede eller en billigere lokal piratkopi. Det samme gælder i Indien. Her har den højtprofilerede aktivist og anti-GM-stjerne Vandana Shiva på vegne af alle indiske småbønder sagt eftertrykkeligt "nej tak!" til GM, men $\mathrm{i}$ indiske landsbyer dyrkes der mere og mere GM og da i særdeleshed de billige indiskfremstillede varianter. I tillæg er der ikke en eneste artikel, der har noget at sige om køn og repræsentativitet i TAM. Der er interessante paradokser her, og det er med dem in mente, at den gode etnografi om sociale bevægelser passende kunne begynde. Med artiklen af Saturino M. Borras Jr. som en delvis undtagelse nøjes flere af bogens artikler $i$ bedste fald (for eksempel Newell) med at identificere paradokset uden egentlig at problematisere det, og det er uheldigt, ikke mindst fordi redaktørerne i deres glimrende introduktion gør en del ud af at understrege, at TAM netop ikke er "single, unitary actors" - og dette burde jo være god antropologisk latin. Redaktørerne påstår også, at artiklerne i bogen sætter kompleksitet i centrum, at de ikke er metodisk afhængige af bevægelsernes lederskikkelser, og at de ikke bygger på forskernes egne velmenende interesser $\mathrm{i}$ at fremme de bevægelser og politiske projekter, de studerer. Men disse påstande bliver altså ikke sande, bare fordi redaktørerne skriver, at sådan er det.

Hvilke nye interessante teoretiske pointer er der så at hente for antropologer med interesse i sociale bevægelser? Der er for eksempel følgende:

Det er ikke altid en fordel at "transnationalisere" en social bevægelse. Gør man det, er der risiko for, at man mister kontakt med græsrødderne (Baletti et al.).

De store TAM som Via Campesina udviser en rystende mangel på interesse for de sociale bevægelser, der ikke er i stand til at organisere sig, fordi de opererer i lande, hvor de undertrykkes af regimet, eksempelvis i Burma (Malseed) og Kina (Walker). Organisering er adgangsbilletten til det gode transnationale selskab.

Det transnationale felt er ikke globalt. De store TAM har stort set ingen tilstedeværelse i Rusland, Centralasien, Mellemøsten, Nordafrika og Kina, og det er netop her, flertallet af verdens fattige bor (Borras Jr. et al.).

De er hermed videreformidlet.

Kenneth Bo Nielsen Ph.d.-studerende Senter for Utvikling og Miljø (SUM)

Universitetet i Oslo 